\title{
Corporate Governance and Earnings Conservatism in Malaysia
}

\begin{abstract}
The objective of this paper is to examine whether earnings conservatism increased after the amendment of corporate governance code in 2007 (MCCG 2007). Based on both asymmetric timeliness by Basu (1997) and accrual-based conservatism models by Ball and Shivakumar (2005), we find that MCCG 2007 enhances earnings conservatism. Our extended analyses of corporate governance variables contribute to the understanding of audit committee independence and audit committee expertise.

JEL classification: M41, M48, G34, G38

Keywords: Earnings conservatism, Malaysia, corporate governance, audit committee, expertise
\end{abstract}




\section{Research Motivations}

Watts (2003a) argues that accounting conservatism facilitates the effective monitoring of managers as part of the governance system, and studies have examined the relationship between conservatism and boards of directors (Ahmed \& Duellman, 2007; Garcia-Lara et al., 2007; Garcia-Lara et al., 2009) financial accounting expertise (Krishnan \& Visvanathan, 2008), institutional ownership (Ramalingegowda \& Yu, 2012) and governance index (Lim, 2011).

This study investigates the relationship between earnings conservatism and corporate governance in Malaysia between 2004 and 2009. A revision of the 2000 Malaysian Code of Corporate Governance (MCCG) took place in 2007, and this time span allows us to investigate the incremental effect of the revision by examining the relationship between corporate governance and earnings conservatism pre- and post2007. The revision of Malaysian Code of Corporate Governance (MCCG) in 2007 marked a significant milestone in corporate governance reform in Malaysia as this code codified the principles and best practices of good governance and described optimal corporate governance structures and internal processes for the listed companies in Malaysia after the release of MCCG in 2000. The governance code is being reviewed to improve the quality of the board of listed firms by having in place the criteria for qualification of directors and strengthening the audit committee, as well as the internal audit function of the firms. The extensive qualifications of board of directors and audit committee in determining good corporate governance practices is expected to be translated into high financial reporting quality.

We extend the examination on this relationship by including two sets of corporate governance variables highlighted by MCCG 2007. The first set, board 
expertise mix, forms our second research objective and we predict a positive relationship with earnings conservatism. Our third research objective is to find a positive relationship between three audit committee characteristics: expertise, independence, and meetings and earnings conservatism.

To ensure robustness of tests on earnings conservatism, we adopt both the market-based test, the timeliness of earnings to news (Basu, 1997) and accountingbased approach, accrual-based loss recognition (Ball \& Shivakumar, 2005). Based on 3,183 observations of Malaysia listed firms during the period 2004-2009, this study finds that earnings conservatism increased after MCCG 2007, supporting the proposition that corporate governance enhances financial reporting quality. We find no evidence that board expertise affected earnings conservatism post-2007. Further analysis reveals that among the variables that lead to the enhancement of conservatism for both market- and accounting-based measures are audit committee expertise and level of audit committee independence. The results also indicate that independence is an important characteristic in an audit committee, as there is a negative relationship between earnings conservatism and the percentage of non-executive directors, and positive relationship between earnings conservatism and the percentage of independent non-executive directors. The result suggests that, in the absence of audit committee independence, increasing the proportion of non-executive directors does not improve the quality of financial reporting.

Our contributions to the existing literature are twofold. First, we extend the literature on earnings conservatism in Malaysia by providing evidence of how corporate governance has influenced conservatism since 2007 by examining the relationship between corporate governance and conservatism before and after the revamp Malaysian 
Code on Corporate Governance in 2007 (MCCG 2007, henceforth). Second, we add to existing corporate governance studies in Malaysia such as Abdul Wahab et al. (2007) which examines the effect of governance reform on performance in 2001 and Lim et al. (2013) which analyse the effect of the 2001 reform on timeliness of earnings.

\section{Empirical Predictions}

\subsubsection{Corporate Governance and Earnings Conservatism ${ }^{1}$}

Since corporate governance is designed to mitigate agency costs between managers and owners/shareholders, conservative accounting can assist in mitigating agency costs in contracts (Garcia-Lara et al., 2009a).

There are two views of the relationship between corporate governance and earnings conservatism. The first, that corporate governance drives earnings conservatism, can be divided into two sub-arguments. Chi et al.(2009) offer two

${ }^{1}$ When studying the association between corporate governance and earnings conservatism, we treat governance structures as exogenous. Our approach is the same as that of Core et al. (1999) where they observe that 'Following most prior empirical research in this area, we treat the board and ownership structures as exogenous, when economic theory would argue that these variables are endogenous.' This well-established approach of treating governance structures as exogenous is reasonable, in the sense that some institutional features of contracting cause governance characteristics to be 'sticky.' For example, directors serve for fixed terms, and it takes time to change board members to adjust to a changed operating environment. Like many prior studies, we argue that it is difficult for firms to have optimal governance structures at all times (e.g., see Larcker et al., 2007). 
competing perspectives: the substitutive perspective that argues that conservatism is greater in situations with more agency problems and that a weak governance structure leads to more conservative accounting (a negative relationship); and the complementary, positive perspective that corporate governance assists in implementing accounting conservatism by helping managers and investors to distinguish between good and bad investment opportunities in a timely manner.

The competing argument is that earnings conservatism may drive corporate governance (Garcia-Lara et al., 2009a). Bushman et al. (2004) find that when earnings timeliness is low, boards adopt stronger governance mechanisms as a substitute for high-quality accounting information.

We argue in tandem with Chi et al. (2009) that stronger corporate governance will enhance conservatism. Conservatism can help managers and investors to identify and distinguish between good and bad investment opportunities, giving important information to investors and preventing managers from misappropriating their wealth. It can also help to reduce information asymmetry among investors by forcing firms to make timely disclosure of high-quality financial accounting information. Based on this argument, we hypothesise, in the alternative form:

$H_{1}$ : There is a positive relationship between earnings conservatism and the MCCG 2007 amendments 


\subsubsection{Board Expertise Mix and Earnings Conservatism}

Fama and Jensen (1983) argue that boards of directors are the central decisionmaking authority in an organisation and that a board of directors may monitor management in a manner that increases their wealth at the expense of firm value. They also have a resource dependency function (Dhaliwal et al., 2010). Resource dependency theory views directors as not as vigilant monitors, but as seeking to improve performance by extracting human capital resources from the environment (Pfeffer, 1972).We apply the resource dependency theory by offering two separate variables on board expertise: ACC_EXPERT represents the percentage of a board of directors with accounting expertise, and FIN_EXPERT represents the percentage of a board of directors with financial expertise.

This hypothesis examines the relationship between a board of directors' accounting and financial expertise and earnings conservatism. Directors with accounting expertise have a better ability to differentiate between conservative and aggressive accounting policies; they have the ability to evaluate the nature and appropriateness of accounting choices made by managers; and as risk of litigation is heavily related accounting expertise, they have strong incentives to promote accounting conservatism.

Based on resource dependency theory, Cohen et al. (2008) argue that nonaccounting expertise can significantly improve the effectiveness of an audit committee as they can assess business risks and determine whether an accounting adoption has economic substance. Dhaliwal et al. (2010) suggest that, based on resource dependency theory, the contribution of finance experts is the most effective non-accounting expertise, as they typically have a strong background in estimating earnings forecasts, 
providing stock recommendations and carrying out due diligence in connection with equity offerings and mergers and acquisitions. Finance experts gather information not only from financial statements but also from a wide range of other resources (Dhaliwal et al., 2010). A mix of accounting (ACC_EXPERT) and finance expertise (FIN_EXPERT) should result in higher earnings quality, and hence better earnings conservatism. We posit the following hypothesis, stated in alternative form:

$\mathrm{H}_{2}$ : The board mix of accounting and financial expertise is positively related to earnings conservatism

\subsubsection{Audit Committee Characteristics and Earnings Conservatism}

Our third hypothesis examines various audit committee characteristics and their effect on earnings conservatism. Audit committees generally function independently of the board of directors, with sufficient authority, resources and assigned responsibilities to assist the entire board in fulfilling its fiduciary duties (Rezaee, 2010).

The three dominant characteristics of audit committees are their independence, the number of meetings they hold annually, and their financial expertise (Ghafran \& O’Sullivan, 2013). We examine these characteristics for their effect on earnings conservatism. Audit committee independence is often considered an essential characteristic, influencing the committee's effectiveness in overseeing the financial reporting process (Baxter \& Cotter, 2009). While there may be independent directors on a board, the independence of an audit committee is more essential, as its composition 
requires a majority of independent directors. We predict a positive relationship between the level of audit committee independence and earnings conservatism. We operationalise our audit committee independence into two variables: $A C \_I N D$, the percentage of an audit committee comprising independent non-executive directors; and $A C \_N E D$, the percentage comprising non-executive directors.

The second characteristic of an audit committee is financial expertise, which is considered to ensure its effectiveness. Defond et al. (2005) argue that financial accounting expertise maybe more important than any other, as audit committee members are responsible for tasks that require a high degree of accounting sophistication. Dhaliwal et al. (2010) argue that accounting expertise in an audit committee is required if the committee to seek answers via accounting and auditing processes and to identify discrepancies in accounts prepared by the management.

Sultana and Van der Zahn (2013) state that financial experts in audit committee have the greatest responsibility for financial reporting because of their superior knowledge and understanding of financial matters and reporting issues.

MCCG 2007 requires that all members of audit committees should be financially literate and at least one should be a member of an accounting association. 'Financially literate' means that 'all its members should be able to read, analyse and interpret financial statements so that they will be able to effectively discharge their functions (Malaysia Securities Commission, 2007)'. As this interpretation is broad, we redefine it to mean that all members have a finance or accounting background, or both. This is because accounting is a subset of finance, and anyone with finance qualifications is expected to be able to read, analyse and interpret financial statements. We offer two variables for expertise in audit committee: AC_FIN_EXPERT, calculated as the 
percentage of an audit committee that is financial literate; and AC_ASSOC, an indicator variable that takes the value of 1 if at least one of the audit committee members is a member of an accounting association body.

Out third audit committee variable is frequency of meetings. As per MCCG 2007, we operationalised our audit committee meetings variables into two variables: the frequency of audit committee meetings (ACMEET) and the frequency of audit committee meetings with external auditor (ACMEET_AUD). Xie et al. (2003) suggest that boards that meet more often are able to devote more time to earnings management or earnings-related issues. Xie et al. (2003) argue that boards that seldom meet risk becoming rubber stamps for management plans, failing in their monitoring duties. Vafeas (2005) suggests that the frequency of audit committee meetings reflects their effectiveness, as higher frequencies of meeting leads to them monitor better. Based on these arguments, we offer the following hypothesis, stated in alternative form:

$H_{3}$ : The independence, expertise and activities of an audit committee are positively related to earnings conservatism

\section{Data and Research Methods}

\subsubsection{Sample Selection and Data Collection}

Our sample consists of 3183 observations of Malaysian firms. Financial institutions, insurance and real estate companies are excluded because of differences in their regulatory frameworks. Delisted firms, firms with non-calendar years and firms 
with missing data are also excluded. The sample is divided into two periods, pre-MCCG 2007 (2004-2006) and post-MCCG 2007 (2007-2009). The year selection is centred on the effective date for implementing amendment MCCG 2007, 01 January 2007.

Data for the Basu (1997) and Ball and Shivakumar (2005) models were collected from Compustat Global. Data such as number of audit committees, number of board of directors, number of meetings and percentage of financial expertise were hand collected, lending uniqueness to our data. Following Vichitsarawong et al. (2009) and Ball et al. (2003), accounting variables are deflated by the beginning of period price to control for heterocedasticity. The 1st and 100th percentiles of each variable are winsorised to reduce the effect of outliers.

\subsubsection{Asymmetric timeliness of earnings}

Asymmetric timeliness of earnings and accounting conservatism were tested using Basu (1997)'s model specification. This model has been tested in Malaysia by Ball et al. (2003) and Vichitsarawong et al. (2010) and is as follows:

$$
N_{i t}=b_{0} \text { Intercept }_{i t}+b_{1} D R_{i t}+b_{2} R_{i t}+b_{3} R_{i t} * D R_{i t}+e_{i t}
$$

(Equation 1)

where $N_{i t}$ is net income before extraordinary items per share of firm $i$, deflated by beginning of period share price; $R_{i t}$ is fiscal year continuously compounded return; and $D R_{i t}$ is dummy variable, taking the value of one if $R_{i t}$ is negative, and zero otherwise. 
In this model, stock return is the independent variable and earnings is the dependent variable. The coefficient on stock return $b_{2}$ measures the sensitivity of accounting income to positive stock returns (a proxy for economic gains). The coefficient $b_{3}$ is the main measurement for earnings conservatism, and measures the incremental sensitivity of accounting income to the incorporation of bad news as measured by negative stock returns (a proxy for economic losses). The total sensitivity of accounting income to negative stock returns is measured by $\left(b_{2}+b_{3}\right)$.

In order to test the relationship between adoption of MCCG 2007 and earnings conservatism, Basu’s (1997) model is employed using a dummy year for the period pre(year 2004 till 2006) and post- MCCG 2007 (2007 till 2009):

$$
\begin{aligned}
& N_{i t}=b_{0} \text { Intercept }_{i t}+b_{1} D R_{i t}+b_{2} R_{i t}+b_{3} R_{i t} * D R_{i t}+b_{4} M C C G_{i t}+b_{5} M C C G^{*} R_{i t}+ \\
& b_{6} M C C G^{*} D R_{i t}+b_{7} M C C G^{*} D R^{*} R_{i t}+e_{i t}
\end{aligned}
$$

(Equation 2)

where all variables are as described above. MCCG takes the value of 1 for the period after MCCG 2007 and 0 otherwise. The coefficient $b_{7}$ measures the relationship between the level of asymmetric timeliness of conservatism and MCCG 2007. It is expected that the coefficient will be positive and significant, showing that earnings conservatism increases after adoption of MCCG 2007.

In order to test $H_{2}$ and $H_{3}$, each corporate governance variable is interacted with each of the variables in Basu's model, as stated below. The equation is run separately for the period before and after MCCG to determine the effect of corporate governance 
variables on earnings conservatism. This study uses panel data analysis to account for individual heterogeneity (Baltagi, 2008).

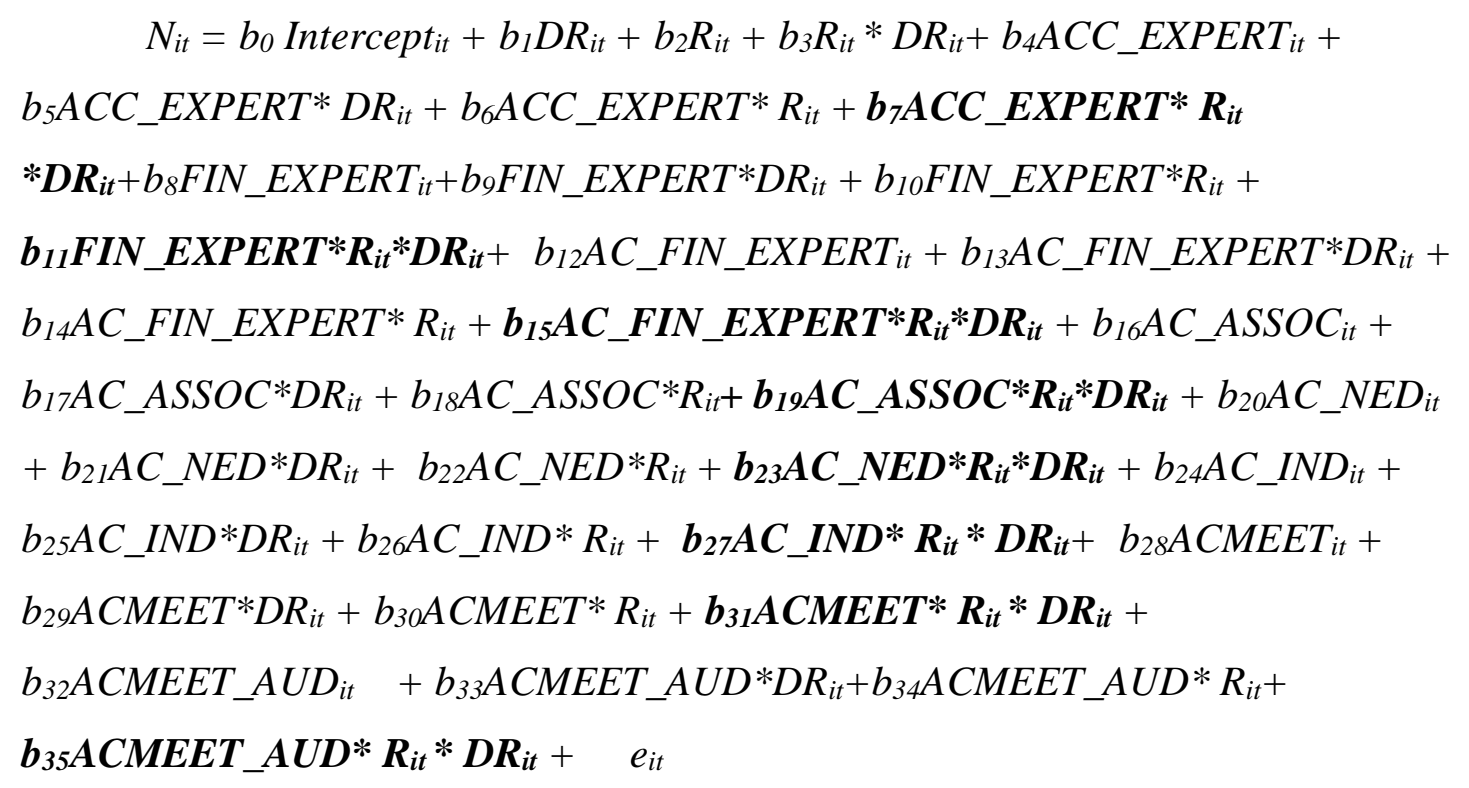

(Equation 3)

The variables of interest are in bold as their coefficients $\left(b_{7}, b_{11}, b_{15}, b_{19}, b_{23}, b_{27}, b_{31}\right.$, and $\left.b_{35}\right)$ reflect the level of earnings conservatism.

\subsubsection{Accrual-based loss recognition}

Ball and Shivakumar (2005) argue that the reverse regression approach assumes asymmetrical and efficient reaction to economic news. As an alternative measure for conservatism, we adopt accrual-based loss recognition, in which accruals are timely in reflecting cash flows. Ball and Shivakumar's (2005) model uses operating cash flow to determine bad news and good news; they argue that accruals incorporate a conservative role where economic losses are more likely to be recognised on a timely basis as 
unrealised accrued charges against income. In contrast, economic gains are more likely to be recognised when realised, and hence are accounted for on a cash basis (Ahmed \& Henry, 2012). The base model for Ball and Shivakumar (2005) model is as follows:

$$
A C C_{i t}=c_{0} \text { Intercept }_{i t}+c_{1} D C F O_{i t}+c_{2} C F O_{i t}+c_{3} C F O_{i t} * D C F O_{i t}+e_{i t}
$$

(Equation 4)

Where $A C C_{i t}$ is accruals (the difference between operating profit and cash flow from operations) scaled by the book value of total assets at the beginning of the fiscal year. $D C F O_{i t}$ takes the value of 1 if the $C F O_{i t}$ is negative, while $C F O_{i t}$ is cash flow from operating activities scaled by the book value of total assets at the beginning of the fiscal year. Like equation 2 above, we have the following regression to test the incremental impact of MCCG:

$$
\begin{gathered}
\text { ACC }_{i t}=c_{0} \text { Intercept }_{i t}+c_{1} \mathrm{DCFO}_{i t}+c_{2} \mathrm{CFO}_{i t}+c_{3} \mathrm{CFO}_{i t} * \mathrm{DCFO}_{i t}+c_{4} \mathrm{MCCG}_{i t}+ \\
c_{5} \mathrm{MCCG}^{*} \mathrm{CFO}_{i t}+c_{6} \mathrm{MCCG}^{*} \mathrm{DCFO}_{i t}+c_{7} \mathrm{MCCG}^{*} \mathrm{DCFO}{ }^{*} C F O_{i t}+e_{i t}
\end{gathered}
$$

(Equation 5)

In order to test $H_{2}$ and $H_{3}$, we have the following accrual-based loss recognition model:

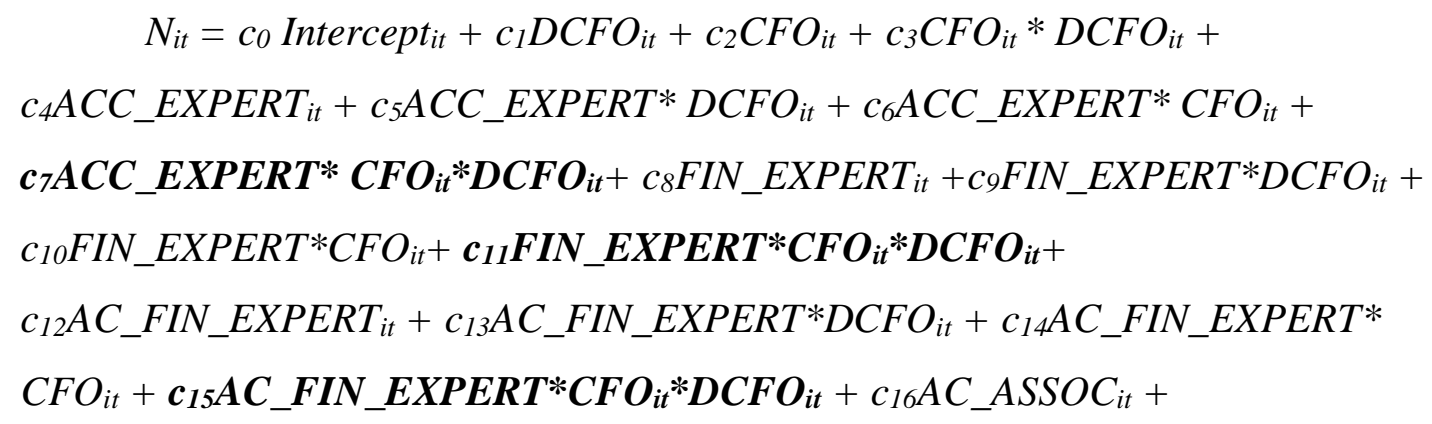


$C_{17} A C \_A S S O C * D C F O_{i t}+c_{18} A C \_A S S O C * C F O_{i t}+c_{19} A C \_A S S O C * C_{-} \boldsymbol{O}_{i t} * \mathbf{D C F O}_{i t}+$ $C_{20} A C \_N E D_{i t}+C_{21} A C \_N E D * D C F O_{i t}+C_{22} A C \_N E D * C F O i t+$

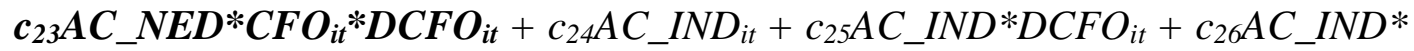

CFOit $+\boldsymbol{c}_{27}$ AC_IND* CFO $_{i t} * \mathbf{D C F O}_{i t}+c_{28} A C M E E T_{i t}+c_{29} A C M E E T * D C F O_{i t}+$

$C_{30} A_{C M E E T *}^{*}$ CFOit + $\boldsymbol{c}_{31}$ ACMEET ${ }^{*}$ CFO $_{i t}{ }^{*}$ DCFO $_{i t}+C_{32} A C M E E T_{-} A U D_{i t}+$

$c_{33} A C M E E T \_A U D * D C F O_{i t}+c_{34} A C M E E T \_A U D * C F O i t+c_{35} A C M E E T \_A U D *$

$\mathrm{CFO}_{i t}{ }^{*} \mathbf{D C F O} \boldsymbol{O}_{i t}+e_{i t}$

(Equation 6)

The variables of interest are in bold as their coefficients $\left(C_{7}, C_{11}, C_{15}, C_{19}, C_{23}, C_{27}, C_{31}\right.$, and $C_{35}$ ) reflect the level of earnings conservatism based on accrual-based loss recognition.

[Insert Table 1 here]

\section{Results}

\subsubsection{Descriptive Statistics}

Table 2 presents differences in the mean and median values of our measures of corporate governance and institutional culture variables for the periods before and after the amendment of MCCG in 2007. The table shows a significant improvement in some of the corporate governance variables after 2007: ACC_EXPERT increases from 24 percent to 26 percent, significant for both $t$-test and Mann-Whitney test. AC_FIN_EXPERT also increases from 38 percent to 40 percent, significant for both $t$ test and Mann-Whitney. AC_IND and AC_NED increase almost 20 percent, from 71.62 percent to 82.68 percent and from 79.08 percent to 93.17 percent respectively. The high 
increment indicates the positive effect of MCCG 2007, but still falls short as MCGG 2007 requires all members of the audit committee to be non-executive directors. ACMEET also improves significantly after MCCG 2007, and other variables such as FIN_EXPERT and AC_ASSOC show an improvement but the difference is not significant. The average ACMEET_AUD shows a significant increment, with a mean increase from 0.251 to 0.807 . This result shows that most firms still do not comply with MCCG 2000, which requires firms to have at least one meeting with external auditors without the presence of executive board members.

[Insert Table 2 here]

\subsubsection{Correlations}

Table 3 presents both Pearson and Spearman-rank correlations for the test variables. Generally, there is no serious multicollinearity issue between the variables. The correlation coefficients are at around 0.3 or lower, except for the correlation coefficient between the corporate governance variables. For example, the Pearson correlation coefficient between ACC_EXPERT and AC_FIN_EXPERT is 0.606 and the Spearman correlation coefficient between AC_NED and AC_IND is 0.517 .

[Insert Table 3 here] 


\subsubsection{Multivariate ${ }^{2}$}

Table 4 reports the regression results of earnings conservatism and MCCG 2007. The intercept is significantly positive (3.806, $t=2.067, p<0.05$ ), as predicted by Basu (1997), showing that earnings conservatism increased after MCCG 2007 and is significant at 5 percent level tabulated in column 2 of Table 4 . We find similar results for accrual-based loss recognition, which depicts an increase in conservatism $(0.272$, $t=1.778, p<0.10$ ) presented in column 4 of Table 4.

The result indicates both the positive effect of MCCG 2000 and the increased positive effect after the amendment MCCG 2007. This supports Abdul Wahab et al. (2007), who consider the establishment of the (MCCG) as one of the recommendations to solve the problem of transparency among firms in Malaysia. Consistent with previous studies (Ahmed \& Duellman, 2007, Garcia-Lara et al., 2009a, Kousenidis et al., 2009, Jiang et al., 2008), the result supports that corporate governance provides greater monitoring of financial reporting and hence firms with strong corporate governance experience significantly improved quality of earnings conservatism.

[Insert Table 4 here]

${ }^{2}$ Consistent with extant literature on conservatism, a number of interaction terms are used in this study. These interaction terms could give rise to potential multicollinearity issues. In some cases, the variance inflation factors are found to be higher than the preferred threshold of 10 . 


\subsubsection{Asymmetric timeliness of Earnings}

Table 5 presents the results of the relationship between corporate governance and earnings conservatism for two separate samples: pre- and post-MCCG 2007. We do not find that the revised MCCG 2007 affects the relationship between board expertise (ACC_EXPERT and FIN_EXPERT) and conservatism. As we find a significant relationship between board expertise (ACC_EXPERT) and conservatism prior to the improvement of the code, this suggests that the revision has had minimal effect on earnings quality in Malaysia. We cannot support the proposition that board expertise mix $\left(H_{2}\right)$ improves earnings conservatism.

This study finds a significant positive relationship between earnings conservatism and the percentage of audit committees that are financially literate $\left(A C \_F I N \_E X P E R T^{*} D R^{*} R\right)$ before and after MCCG $2007 \quad(0.208, t=2.175$, $p<0.05$ ), (column 3, Table 5); this supports the hypothesis that MCCG 2007 enhances earnings conservatism, and supports the view that audit committees that have financial expertise are less likely to engage in fraudulent financial reporting (Farber, 2005) and earnings restatements (Abbott et al., 2004; Agrawal \& Chadwa, 2005), and more likely to have forecast updates (Karamanou \& Vafeas, 2005).

Further, we find that there is significant negative relationship between conservatism and being a member of an accounting association body $\left(A C \_A S S O C^{*} D R^{*} R\right)$ after MCCG 2007 (-11.342, $\left.t=-1.722, p<0.10\right)$, (column 3, Table 5). We conclude that having an accounting qualification is more vital in enhancing earnings conservatism than having specific accounting experience or being a member of an accounting association or body. We therefore reject the view that effective audit 
committee members are those who have experience, rather than those who have an accounting or financial background.

Table 5 provides no evidence to support the contention that the proportion of non-executive directors on audit committee can enhance earnings conservatism; as the tables show, there is a significant negative relationship between earnings conservatism and $A C \_N E D$ after MCCG 2007 (AC_NED*DR*R); the result was significant and positive before MCCG 2007. Nevertheless, the proportion of independent nonexecutive audit committee members $\left(A C \_I N D^{*} D R^{*} R\right)$ enhances earnings conservatism as the result is significantly positive $(0.176, t=1.738, p<0.10)$ after MCCG 2007.

Contrary to past studies which document that a higher frequency of audit meetings is associated with factors that enhance financial reporting quality (Kent et al., 2010; Koh et al., 2007; Vafeas, 2005; Xie et al., 2003), we find a negative significant relationship between earnings conservatism $(-3.128, t=-2.977, p<0.010)$ and the number of audit committee meetings $\left(A C M E E T^{*} D R^{*} R\right)$ (column 3, Table 5). There is a negative relationship between earnings conservatism and ACMEET that becomes even stronger after MCCG 2007, and is significant at 1 percent level.

Result indicate that audit committee meetings are an indicator of the overall demand for monitoring a firm's financial reporting (Engel et al., 2010; GoodwinStewart \& Kent, 2006), which is believed to translate into greater transparency. However, too many meetings in a year may lead to lower reporting quality if audit committees use the time to discuss issues unrelated to their monitoring task.

Table 5 provides regression results for audit committee meetings measured by ACMEET_AUD (ACMEET_AUD*DR*R). The MCCG 2000 was amended in 2007 to increase the number of audit committee meetings, with an external auditor but without 
the present of executive members, from one to two meetings per year. The objective of our test is not simply to determine the effect of audit committee meetings on earnings conservatism, but to test the independence of their audit committee now the code requires some meetings to be held without the presence of executive board members. Our result indicates that the interaction variable $A C M E E T \_A U D^{*} D R^{*} R$ was insignificant even before MCCG 2007, and we therefore find no evidence to indicate that such meetings enhance financial reporting quality.

[Insert Table 5 here]

\subsubsection{Accrual-based loss recognition}

Table 6 presents regression results based on the accrual-based loss recognition developed by Ball and Shivakumar (2005) modified to measure the incremental conservatism associated with corporate governance variables. We find a significant and positive relationship between AC_FIN_EXPERT and ACC after MCCG 2007 (0.031, $t=5.047, p<0.01$ ) (column 4, Table 6), and a negative and significant relationship between AC_ASSOC and ACC before and after MCCG 2007. We also find a positive and significant relationship between $A C \_M E E T$ and $A C C$ after the introduction of MCCG 2007. Our significant findings for accrual-based loss recognition are similar to those based on the Basu (1997) asymmetric timeliness of earnings model.

[Insert Table 6 here] 


\section{Conclusion}

This study examines the relationship between corporate governance and earnings conservatism in Malaysia. Our first objective was to investigate whether the change in corporate governance in 2007 through a revision of MCCG enhances conservatism. Our second objective was to examine whether board expertise, both finance and accounting, improves conservatism. Our third objective was to test whether audit committee characteristics affect conservatism.

Based on 3,183 firm-year observations during 2004-2009, and utilising both accounting and market-based conservatism measures, we find that the revision of MCCG 2007 resulted in increased conservatism. We find no support that board expertise in accounting and finance resulted in increased conservatism. Only financial expertise and audit committee independence resulted in improved conservatism. Other audit committee characteristics resulted in decreased conservatism after 2007, including member association, the presence of non-executive directors on the committee (only for accounting-based conservatism) and the frequency of meetings.

The result of the study highlight that the characteristic of audit committee is more vital in enhancing financial reporting quality. The importance of audit committee role has also been highlighted in an overall of Malaysia's performance in Corporate Governance Watch 2010 which reported that the main weaknesses in Malaysia's CG score is whether audit committees are truly independent and accountable in implementing their task. Our results suggest that the MCCG 2007 revision has affected earnings quality in Malaysia, and that the financial expertise and independence of the audit committee is essential in determining the level of conservatism in Malaysia. Our 
study is not without any caveats. We do acknowledged the subject of endogeneity faced by corporate governance studies which warrant further analysis. 


\section{References}

Abbott, L. J., Parker, S. \& Peters, G. F. (2004). "Audit Committee Characteristics and Restatements". Auditing: A Journal of Practice \& Theory,Vol. 23,pp. 69-87.

Abdul Wahab, E. A., How, J. C. Y. \& Verhoeven, P. (2007). "The Impact of the Malaysian Code on Corporate Governance: Compliance, Institutional Investors and Stock Performance."Journal of Contemporary Accounting \& Economics,Vol. 3,No. 2, pp. 106-129.

Agrawal, A. \& Chadwa, S. (2005),"Corporate Governance and Accounting Scandals."Journal of Law and Economics, Vol. 48,pp. 371-406.

Ahmed, A. S. \& Duellman, S. (2007). "Accounting Conservatism and Board of Director Characteristics: An Empirical Analysis."Journal of Accounting and Economics, Vol. 43,pp. 411-437.

Ahmed, K., \& Henry, D. (2012). Accounting Conservatism And Voluntary Corporate Governance Mechanisms By Australian Firms. Accounting \& Finance, Vol. 52 No.3, pp. 631-662.

Anderson, R. C., Mansi, S. A. \& Reeb, D. M. (2004). "Board Characteristics, Accounting Report Integrity,and The Cost of Debt."Journal of Accounting and Economics,Vol. 37,pp. 315-342.

Ball, R., Robin, A. \& Shuang Wu, J. (2003.)"Incentives versus Standards: Properties of Accounting Income in Four East Asian Countries."Journal of Accounting and Economics, Vol. 36,pp. 235-270.

Ball, R. \& Shivakumar, L. (2005). "Earnings Quality in UK Private Firms:Comparative Loss Recognition Timeliness."Journal of Accounting and Economics,Vol. 39,pp. 83128.

Baltagi, B. H. (2008). "Econometric Analysis of Panel Data, The Atrium, Southern Gate, Chichester, West Sussex, Po19 8sq, Uk, John Wiley \& Sons Ltd."

Basu, S. (1997). "The Conservatism Principle and The Asymmetric Timeliness of Earnings."Journal of Accounting and Economics, Vol. 24, pp. 3-37.

Baxter, P., \& Cotter, J. (2009). "Audit Committees and Earnings Quality."Accounting \& Finance, Vol.49 No. 2, pp. 267-290. 
Bushman, R., Piotroski, J. \& Smith, A., (2004). "What Determines Corporate Transparency?"Journal of Accounting Research, Vol. 42 No. 2, pp.207-252.

Chi, W., Liu, C. \& Wang, T. (2009). "What Affects Accounting Conservatism: A Corporate Governance Perspective."Journal of Contemporary Accounting and Economics, Vol. 5,pp. 47-59.

Cohen, J. R., Krishnamoorthy, G., \& Wright, A. M. (2008). "Form Versus Substance: The Implications For Auditing Practice And Research Of Alternative Perspectives On Corporate Governance" Auditing: A Journal of Practice \& Theory, Vol. 27 No.2, pp. 181-198.

Core, J. E., Holthausen, R. W., and Larcker, D. F. (1999). “Corporate Governance, Chief Executive Office Compensation, and Firm Performance.” Journal of Financial Economics, Vol. 51, pp. 371-406.

Davidson III, W. N., Xie, B., \& Xu, W. (2004). "Market Reaction To Voluntary Announcements of Audit Committee Appointments: The Effect of Financial Expertise."Journal of Accounting and Public Policy, Vol.23No.4, pp. 279-293.

DeFond, M. L., Hann, R. N., \& Hu, X. (2005). "Does The Market Value Financial Expertise On Audit Committees Of Boards Of Directors?" Journal of Accounting Research, Vol. 43 No. 2, pp. 153-193.

DeZoort, F. T., Hermanson, D. R., Archambeault, D. S., \& Reed, S. A. (2002). "Audit Committee Effectiveness: A Synthesis of the Empirical Audit Committee Literature". Journal of Accounting Literature, Vol. 21, pp. 38-75.

Dhaliwal, D. A. N., Naiker, V. I. C., \& Navissi, F. (2010). "The Association between Accruals Quality and the Characteristics of Accounting Experts and Mix of Expertise on Audit Committees". Contemporary Accounting Research, Vol. 27 No. 3, pp. 787827.

Engel, E., Hayes, R. M., \& Wang, X. (2010). "Audit Committee Compensation and Demand for Monitoring of the Financial Reporting Process." Journal of Accounting and Economics,Vol.49No.1-2, pp. 136-154.

Fama, E. F. \& Jensen, M. C. (1983). "Separation of Ownership and Control". Journal of Law and Economics, Vol. 26,pp.301-325.

Farber, D. (2005). "Restoring Trust After Fraud: Does Corporate Governance Matter?"The Accounting Review,Vol. 80,pp. 539-561. 
García Lara, J. M., Osma, B. G., \& Penalva, F. (2007). "Board of Directors' Characteristics and Conditional Accounting Conservatism: Spanish Evidence."European Accounting Review, Vol.16 No.4, pp. 727-755.

Garcia Lara, J. M., Osma, B. G., \& Penalva, F. (2009). "Accounting Conservatism and Corporate Governance."Review of Accounting Studies, Vol.14 No.1, pp.161-201.

Ghafran, C., \& O'Sullivan, N. (2013). "The Governance Role of Audit Committees: Reviewing a Decade of Evidence."International Journal of Management Reviews, Vol.15No.4, pp. 381-407.

Goodwin-Stewart, J., \& Kent, P. (2006). "Relation between External Audit Fees, Audit Committee Characteristics and Internal Audit."Accounting \& Finance, Vol.46 No.3, pp. 387-404.

Jiang, W., Lee, P. \& Anandarajan, A. (2008). "The Association Between Corporate Governance and Earnings Quality: Further Evidence Using Gov-Score."Advances in Accounting, Incorporating Advancesin International Accounting,Vol. 24,pp.191-201.

Karamanou, I. \& Vafeas, N. (2005). "The Association between Corporate Boards, Audit Committees, and Management Earnings Forecasts: An Empirical Analysis."Journal of Accounting Research,Vol. 43,pp.453-486.

Kent, P., Routledge, J., \& Stewart, J. (2010). "Innate and Discretionary Accruals Quality and Corporate Governance". Accounting \& Finance, Vol. 50 No.1, pp.171-195.

Koh, P. S., Laplante, S. K., \& Tong, Y. H. (2007). "Accountability and Value Enhancement Roles of Corporate Governance."Accounting \& Finance, Vol.47 No. 2, pp. 305-333.

Kousenidis, D. V., Ladas, A. C. \& Negakis, C. I. (2009). "Value Relevance of Conservatisve and Non-Conservative Accounting Information."The International Journal of Accounting,Vol. 44, pp. 219-238.

Krishnan, G. V. \& Visvanathan, G. (2008). "Does The Sox Definition of An Accounting Expert Matter? The Association Between Audit Committee Directors' Accounting Expertise and Accounting Conservatism."Contemporary Accounting Research,Vol. 25, pp. 827-858.

Larcker, D. F., Richardson, S. A., and Tuna, Ä․ (2007). “Corporate Governance, Accounting Outcomes, and Organizational Performance.” Accounting Review, Vol. 82 No. 4, 963-1008. 
Lim, R. (2011). "Are Corporate Governance Attributes Associated with Accounting Conservatism?"Accounting \& Finance, Vol. 51 No.4, pp.1007-1030.

Lim, M., How, J., \& Verhoeven, P. (2013). "Corporate Ownership, Corporate Governance Reform and Timeliness of Earnings: Malaysian Evidence."Journal of Contemporary Accounting \& Economics, Vol.10 No.1, pp. 32-45.

Malaysia Securities Commission. (2007). Malaysian Code of Corporate Governance (Revised 2007). Retrieved from www.sc.com.my.

Mohamed Yunos, R., Ismail, Z., \& Smith, M. (2012). "Ethnicity and Accounting Conservatism: Malaysian Evidence."Asian Review of Accounting, Vol.20 No.1, pp. 3457.

Pfeffer, J. (1972). "Size and Composition of Corporate Boards of Directors: The Organization and its Environment" Administrative Science Quarterly, Vol. 17 No.2, pp. 218-228.

Ramalingegowda, S., \& Yu, Y. (2012). "Institutional Ownership and Conservatism."Journal of Accounting and Economics, Vol.53No.1, pp. 98-114.

Rezaee, Z. (2010). "Board Subcommittees for Corporate Governance. In Corporate Governance: A Synthesis of Theory, Research and Practice"-Robert W. Kolb Series in Finance (pp. 243-262).

Sultana, N., der Zahn, V., \& Mitchell, J. L. (2013). "Earnings Conservatism and Audit Committee Financial Expertise."Accounting \& Finance.

Vafeas, N. (2005). "Audit Committees, Boards, and The Quality of Reported Earnings."Contemporary Accounting Research, Vol. 22 No.4, pp.1093-1122.

Vichitsarawong, T., Eng, L. L. \& Meek, G. K. (2010). "The Impact of The Asian Financial Crisis on Conservatism and Timeliness of Earnings: Evidence From Hong Kong, Malaysia, Singapore, and Thailand."Journal of International Financial Management and Accounting, Vol. 21, pp. 32-61.

Watts, R. L. (2003)a. "Conservatism in Accounting Part I: Explanations and Implications". Accounting Horizons, Vol. 17, pp. 207-221.

Watts, R. L. (2003b). "Conservatism in Accounting Part II: Evidence and Research Opportunities."Accounting Horizons, Vol. 17, pp.287-301. 
Xie, B., Davidson, W. N., \& DaDalt, P. J. (2003). "Earnings Management and Corporate Governance: The Roles of the Board and the Audit Committee."Journal of Corporate Finance, Vol.9 No.3, pp. 295-316.

Zhang, Y., Zhou, J. \& Zhou, N. (2007). "Audit Committee Quality, Auditor Independence, and Internal Control Weaknesses."Journal of Accounting and Public Policy,Vol. 26,pp. 300-327. 
Table 1: Operational Definition of Variables
Symbol
Definition

Panel A: Asymmetric timeliness of earnings

$N_{i t}$

$R_{\text {it }}$

$D R_{i t}$

Panel B: Accrual-based loss recognition

$A C C_{i t}$

$\mathrm{CFO}_{\text {it }}$

$D_{C F O}$

Panel C: Corporate Governance Variables

ACC_EXPERT $T_{i t}$

FIN_EXPERT $T_{\text {it }}$

AC_FIN_EXPERT $T_{i t}$

AC_ASSOC it

$A C_{-} I N D_{i t}$

$A C \_N E D_{\text {it }}$

ACMEET $T_{\text {it }}$

ACMEET_AUD $D_{i t}$ net income before extraordinary items per share of firm i, deflated by beginning of period share price

fiscal year continuously compounded return

dummy variable that takes the value of one if return is negative, and zero otherwise

accruals (the difference between operating profit and cash flow from operations) scaled by the book value of total assets at the beginning of fiscal year.

cash flow from operating activities scaled by the book value of total assets at the beginning of the fiscal year.

takes the value of 1 if the CFOit is negative

calculated as percentage of board of directors that has accounting expertise

calculated as percentage of board of directors that has finance expertise

calculated as percentage of audit committee that are financially literate

dummy variable; coded as ' 1 ' if at least one of the audit committee being a member of an accounting association and ' 0 ' otherwise

calculated as percentage of audit committee that are independent nonexecutive directors

calculated as percentage of audit committee that are non-executive directors

calculated as number of meetings held by audit committee

Calculated as how many times audit committees conducted meetings with external auditors 
Table 2: Descriptive Statistics

\begin{tabular}{|c|c|c|c|c|c|c|c|c|}
\hline & \multicolumn{3}{|c|}{ Pre MCCG $(\mathrm{n}=1384)$} & \multicolumn{3}{|c|}{ Post MCCG $(\mathrm{n}=1799)$} & \multirow[b]{2}{*}{$\begin{array}{c}\text { t-test } \\
\text { p-value }\end{array}$} & \multirow[b]{2}{*}{$\begin{array}{c}\text { Mann-Whitney } \\
\text { p-value }\end{array}$} \\
\hline & Mean & Median & Std. Dev & Mean & Median & Std. Dev. & & \\
\hline \multicolumn{9}{|c|}{ Panel A - Earnings Conservatism } \\
\hline$N_{i t}$ & 4.247 & 0.000 & 11.050 & 4.502 & 0.000 & 12.416 & 0.646 & 0.728 \\
\hline$R_{i t}$ & 1.113 & 0.926 & 1.117 & 1.214 & 1.000 & 1.121 & 0.006 & 0.000 \\
\hline$R(\log )$ & -0.119 & -0.077 & 0.637 & -0.027 & 0.000 & 0.636 & 0.000 & 0.000 \\
\hline$D R_{i t}$ & 0.568 & 1.000 & 0.496 & 0.464 & 0.000 & 0.499 & $(0.000)$ & \\
\hline \multicolumn{9}{|c|}{ Panel B: Accrual-based loss recognition } \\
\hline$A C C_{i t}$ & -0.014 & -0.009 & 0.131 & -0.007 & -0.003 & 0.137 & 0.117 & \\
\hline $\mathrm{DCFO}_{i t}$ & 0.197 & 0.000 & 0.398 & 0.220 & 0.000 & 0.414 & $(0.112)$ & \\
\hline$C F O_{i t}$ & 0.062 & 0.055 & 0.098 & 0.050 & 0.045 & 0.084 & 0.000 & 0.000 \\
\hline \multicolumn{9}{|c|}{ Panel B - Corporate Governance Variables } \\
\hline ACC_EXPERT $T_{i t}$ & 23.615 & 20.000 & 13.284 & 26.387 & 25.000 & 14.104 & 0.000 & 0.000 \\
\hline$F I N \_E X P E R T_{i t}$ & 1.924 & 0.000 & 5.487 & 1.955 & 0.000 & 5.467 & 0.885 & 0.850 \\
\hline AC_FIN_EXPERT $T_{i t}$ & 37.783 & 33.333 & 18.359 & 39.725 & 33.333 & 18.868 & 0.002 & 0.000 \\
\hline$A C \_A S S O C_{i t}$ & 0.934 & 1.000 & 0.248 & 0.934 & 1.000 & 0.248 & $(0.990)$ & \\
\hline$A C \_N E D_{i t}$ & 79.079 & 75.000 & 14.381 & 93.174 & 100.000 & 12.828 & 0.000 & 0.000 \\
\hline$A C \_I N D_{i t}$ & 71.616 & 66.667 & 9.632 & 82.678 & 75.000 & 15.780 & 0.000 & 0.000 \\
\hline$A C M E E T_{i t}$ & 4.860 & 5.000 & 1.249 & 4.939 & 5.000 & 1.296 & 0.084 & 0.016 \\
\hline ACMEET_AUD ${ }_{i t}$ & 0.251 & 0.000 & 0.472 & 0.807 & 1.000 & 0.768 & 0.000 & 0.000 \\
\hline
\end{tabular}

Please refer Table 1 for variables description. Significant p-values are bold. Chi-square figures are in parenthesis. 
Table 3: Correlation Matrix

\begin{tabular}{|c|c|c|c|c|c|c|c|c|c|c|c|c|c|c|c|}
\hline & & 1 & 2 & 3 & 4 & 5 & 6 & 7 & 8 & 9 & 10 & 11 & 12 & 13 & 14 \\
\hline$N_{i t}$ & 1 & & $0.175^{\wedge}$ & $-0.074 \wedge$ & $0.097 \wedge$ & $0.191^{\wedge}$ & $-0.142^{\wedge}$ & -0.021 & -0.025 & -0.015 & 0.013 & 0.008 & 0.020 & -0.006 & 0.000 \\
\hline$A C C_{i t}$ & 2 & $0.250^{\wedge}$ & & $0.236^{\wedge}$ & $-0.300^{\wedge}$ & $0.089 \wedge$ & $-0.071^{\wedge}$ & -0.001 & 0.000 & -0.006 & $0.050^{\wedge}$ & $-0.047 \wedge$ & -0.015 & $-0.092^{\wedge}$ & 0.008 \\
\hline$D_{C F O}{ }_{i t}$ & 3 & $-0.079 \wedge$ & $0.367 \wedge$ & & -0.606 & $-0.050^{\wedge}$ & $0.050^{\wedge}$ & -0.023 & 0.007 & $-0.030 \#$ & $-0.041^{*}$ & -0.021 & 0.005 & 0.029 & $-0.046^{\wedge}$ \\
\hline$C F O_{i t}$ & 4 & $0.126^{\wedge}$ & $-0.452^{\wedge}$ & $-0.702^{\wedge}$ & & $0.079 \wedge$ & $-0.053^{\wedge}$ & 0.010 & 0.018 & 0.023 & 0.027 & $0.069^{\wedge}$ & -0.003 & $-0.041 *$ & $0.077 \wedge$ \\
\hline$R_{i t}$ & 5 & $0.141^{\wedge}$ & $0.079 \wedge$ & $-0.059 \wedge$ & $0.083^{\wedge}$ & & $-0.730^{\wedge}$ & 0.024 & -0.016 & 0.009 & $0.031 \#$ & $0.052^{\wedge}$ & $0.037^{*}$ & $-0.058^{\wedge}$ & $0.055^{\wedge}$ \\
\hline$D R_{i t}$ & 6 & $-0.119 \wedge$ & $-0.072^{\wedge}$ & $0.050^{\wedge}$ & $-0.063^{\wedge}$ & $-0.866^{\wedge}$ & & -0.022 & -0.018 & -0.006 & -0.021 & $-0.075^{\wedge}$ & $-0.049 \wedge$ & $0.042^{*}$ & $-0.079^{\wedge}$ \\
\hline$A_{C C} \_X X P R T_{i t}$ & 7 & $-0.047 \wedge$ & -0.022 & -0.013 & 0.004 & 0.014 & -0.013 & & $-0.071^{\wedge}$ & $0.604 \wedge$ & $0.232^{\wedge}$ & $0.151^{\wedge}$ & $0.058^{\wedge}$ & $0.044^{*}$ & $0.107 \wedge$ \\
\hline$F I N \_E X P E R T_{i t}$ & 8 & -0.028 & 0.002 & 0.011 & 0.009 & -0.004 & -0.018 & $-0.057 \wedge$ & & $0.098^{\wedge}$ & $-0.114^{\wedge}$ & -0.013 & -0.003 & 0.014 & -0.009 \\
\hline AC_FIN_EXPERT $T_{i t}$ & 9 & $-0.038 *$ & $-0.036^{*}$ & -0.018 & 0.029 & -0.003 & 0.004 & $0.552^{\wedge}$ & $0.105^{\wedge}$ & & $0.276^{\wedge}$ & $0.061^{\wedge}$ & $0.051^{\wedge}$ & $0.032 \#$ & $0.052^{\wedge}$ \\
\hline$A C \_A S S O C_{i t}$ & 10 & 0.029 & 0.022 & -0.041 & $0.035^{*}$ & 0.029 & -0.021 & $0.217 \wedge$ & $-0.104 \wedge$ & $0.227 \wedge$ & & 0.039 & $0.034 \#$ & 0.021 & $0.054 \wedge$ \\
\hline$A C \_N E D_{i t}$ & 11 & -0.012 & $-0.051^{\wedge}$ & -0.023 & $0.066^{\wedge}$ & $0.062^{\wedge}$ & $-0.075^{\wedge}$ & $0.163^{\wedge}$ & -0.002 & $0.075^{\wedge}$ & 0.043 & & $0.544 \wedge$ & $0.106^{\wedge}$ & $0.382^{\wedge}$ \\
\hline$A C \_I N D_{i t}$ & 12 & 0.021 & -0.010 & -0.001 & 0.008 & $0.035 \#$ & $-0.047 \wedge$ & $0.067 \wedge$ & -0.005 & 0.010 & 0.045 & $0.518^{\wedge}$ & & $0.051^{\wedge}$ & $0.309 \wedge$ \\
\hline$A C \_M E E T_{i t}$ & 13 & -0.018 & $-0.050^{\wedge}$ & $0.033 \#$ & $-0.064 \wedge$ & $-0.039 *$ & 0.027 & 0.020 & 0.036 & -0.011 & 0.012 & $0.092^{\wedge}$ & $0.068^{\wedge}$ & & $0.124 \wedge$ \\
\hline ACMEET_AUD $D_{i t}$ & 14 & 0.010 & 0.002 & -0.045 & $0.076^{\wedge}$ & $0.065^{\wedge}$ & $-0.076^{\wedge}$ & $0.105^{\wedge}$ & 0.004 & $0.055^{\wedge}$ & $0.050^{\wedge}$ & $0.385^{\wedge}$ & $0.284 \wedge$ & $0.116^{\wedge}$ & \\
\hline
\end{tabular}

Please refer Table 1 for variables description. Pearson (italicised) and Spearman Rank correlations are reported in the table.*, \# and $\wedge$ denote significance at the 10 percent, 5 percent and 1 percent level respectively. 
Table 4: Earnings Conservatism and Corporate Governance

\begin{tabular}{|c|c|c|c|c|c|c|c|c|}
\hline \multirow[b]{2}{*}{ Variable } & \multicolumn{3}{|c|}{$\begin{array}{c}\text { Basu (1997) } \\
\text { Asymmetric Timeliness of } \\
\text { Earnings } \\
\end{array}$} & \multicolumn{5}{|c|}{$\begin{array}{l}\text { Ball and Shivakumar (2005) } \\
\text { Accrual-based loss recognition }\end{array}$} \\
\hline & $\begin{array}{c}\text { Coefficient } \\
1 \\
\end{array}$ & & $\begin{array}{c}\text { Coefficient } \\
2 \\
\end{array}$ & & $\begin{array}{c}\text { Coefficient } \\
3 \\
\end{array}$ & & $\begin{array}{c}\text { Coefficient } \\
4 \\
\end{array}$ & \\
\hline$\overline{C_{i t}}$ & 4.139 & & 3.449 & & 0.007 & & 0.000 & \\
\hline & 8.974 & $* * *$ & 5.879 & $* * *$ & 1.887 & $*$ & -0.077 & \\
\hline$D R_{i t}$ & $\begin{array}{l}-0.835 \\
-1.353\end{array}$ & & $\begin{array}{l}-0.443 \\
-0.549\end{array}$ & & & & & \\
\hline$R_{i t}$ & $\begin{array}{l}5.344 \\
7.516\end{array}$ & $* * *$ & $\begin{array}{l}7.795 \\
7.897\end{array}$ & $* * *$ & & & & \\
\hline$D R^{*} R_{i t}$ & $\begin{array}{l}-3.488 \\
-3.445\end{array}$ & $* * *$ & $\begin{array}{l}-6.533 \\
-4.978\end{array}$ & $* * *$ & & & & \\
\hline$D_{C F O}$ & & & & & $\begin{array}{l}0.029 \\
4.624\end{array}$ & $* * *$ & $\begin{array}{l}0.029 \\
2.823\end{array}$ & $* *$ \\
\hline$C F O_{i t}$ & & & & & -0.430 & & -0.361 & \\
\hline$D_{C F O}^{*} C F O_{i t}$ & & & & & $\begin{array}{l}-14.185 \\
-0.077 \\
-1.079\end{array}$ & $* * *$ & $\begin{array}{l}-6.313 \\
-0.267 \\
-2.069\end{array}$ & $* *$ \\
\hline$M C C G_{i t}$ & & & $\begin{array}{l}0.431 \\
0.553\end{array}$ & & & & $\begin{array}{l}0.010 \\
1.451\end{array}$ & \\
\hline$M C C G^{*} D R_{i t}$ & & & $\begin{array}{l}0.288 \\
0.254\end{array}$ & & & & & \\
\hline$M C C G^{*} R_{i t}$ & & & $\begin{array}{l}-3.710 \\
-2.738\end{array}$ & $* *$ & & & & \\
\hline$M C C G^{*} D R^{*} R_{i t}$ & & & $\begin{array}{l}3.806 \\
2.067\end{array}$ & $* *$ & & & & \\
\hline$M C C G^{*} D C F O_{i t}$ & & & & & & & $\begin{array}{l}0.000 \\
0.037\end{array}$ & \\
\hline$M C C G^{*} C F O_{i t}$ & & & & & & & $\begin{array}{l}-0.094 \\
-1.452\end{array}$ & \\
\hline$M_{C C G}{ }^{*} C F O * D C F O_{i t}$ & & & & & & & $\begin{array}{l}0.272 \\
1.778\end{array}$ & * \\
\hline Adjusted $R^{2}$ & 0.042 & & 0.042 & & 0.096 & & 0.093 & \\
\hline F-statistic & 18.757 & $* * *$ & 21.331 & $* * *$ & 43.642 & $* * *$ & 48.093 & $* * *$ \\
\hline
\end{tabular}

Please refer Table 1 for variables description. *, ** and ${ }^{* * *}$ denote significance at the 10 percent, 5 percent and 1 percent level respectively. 
Table 5: Asymmetric Timeliness of Earnings

\begin{tabular}{|c|c|c|c|c|c|c|c|c|}
\hline \multirow{3}{*}{ Variable } & \multicolumn{4}{|c|}{ Pre MCCG $(\mathrm{n}=1384)$} & \multicolumn{4}{|c|}{ Post MCCG (n=1799) } \\
\hline & Coefficient & & Coefficient & & Coefficient & & Coefficient & \\
\hline & 1 & & 2 & & 3 & & 4 & \\
\hline \multirow[t]{2}{*}{ Intercept $_{i t}$} & -5.768 & & -4.406 & & 15.640 & & 15.605 & \\
\hline & -0.945 & & -0.723 & & 2.614 & $* * *$ & 2.538 & ** \\
\hline \multirow[t]{2}{*}{$D R_{i t}$} & 3.530 & & 1.660 & & -8.575 & & -7.725 & \\
\hline & 0.449 & & 0.211 & & -1.107 & & -0.996 & \\
\hline \multirow[t]{2}{*}{$R_{i t}$} & 35.299 & & 33.197 & & -15.663 & & -16.014 & \\
\hline & 3.696 & $* * *$ & 3.483 & $* * *$ & -1.692 & * & -1.731 & * \\
\hline \multirow[t]{2}{*}{$D R^{*} R_{i t}$} & -36.599 & & -34.244 & & 19.458 & & 20.699 & \\
\hline & -2.776 & $* * *$ & -2.598 & $* * *$ & 1.539 & & 1.634 & \\
\hline \multirow[t]{2}{*}{$A C C \_E X P E R T_{i t}$} & -0.109 & & -0.106 & & -0.028 & & -0.028 & \\
\hline & -1.764 & * & -1.717 & * & -0.536 & & -0.531 & \\
\hline \multirow[t]{2}{*}{$A C C_{-} E X P E R T^{*} D R_{i t}$} & 0.040 & & 0.037 & & -0.022 & & -0.021 & \\
\hline & 0.455 & & 0.429 & & -0.293 & & -0.268 & \\
\hline \multirow[t]{2}{*}{$A C C \_E X P E R T^{*} R_{i t}$} & 0.350 & & 0.344 & & -0.109 & & -0.108 & \\
\hline & 3.266 & $* * *$ & 3.216 & $* * *$ & -1.347 & & -1.344 & \\
\hline \multirow[t]{2}{*}{$A C C \_E X P E R T^{*} D R^{*} R_{i t}$} & -0.474 & & -0.470 & & 0.074 & & 0.076 & \\
\hline & -3.286 & $* * *$ & -3.267 & $* * *$ & 0.620 & & 0.643 & \\
\hline \multirow[t]{2}{*}{$F I N \_E X P E R T_{i t}$} & 0.000 & & -0.013 & & -0.151 & & -0.147 & \\
\hline & -0.003 & & -0.115 & & -1.362 & & -1.317 & \\
\hline \multirow[t]{2}{*}{$F I N \_E X P E R T^{*} D R_{i t}$} & -0.016 & & -0.005 & & 0.048 & & 0.045 & \\
\hline & -0.093 & & -0.030 & & 0.303 & & 0.281 & \\
\hline
\end{tabular}

(The table is continued on the next page) 


\begin{tabular}{|c|c|c|c|c|c|c|c|c|}
\hline \multirow[t]{2}{*}{$F I N \_E X P E R T^{*} R_{i t}$} & 0.000 & & 0.022 & & -0.048 & & -0.059 & \\
\hline & -0.001 & & 0.103 & & -0.260 & & -0.317 & \\
\hline \multirow[t]{2}{*}{$F I N \_E X P E R T^{*} D R^{*} R_{i t}$} & -0.062 & & -0.087 & & -0.067 & & -0.056 & \\
\hline & -0.219 & & -0.311 & & -0.270 & & -0.227 & \\
\hline \multirow[t]{2}{*}{$A C \_F I N \_E X P E R T_{i t}$} & 0.056 & & 0.057 & & 0.075 & & 0.074 & \\
\hline & 1.214 & & 1.234 & & 1.822 & $*$ & 1.819 & $*$ \\
\hline \multirow[t]{2}{*}{$A C \_F I N \_E X P E R T^{*} D R_{i t}$} & -0.040 & & -0.041 & & -0.022 & & -0.022 & \\
\hline & -0.650 & & -0.654 & & -0.380 & & -0.370 & \\
\hline \multirow[t]{2}{*}{$A C \_F I N \_E X P E R T^{*} R_{i t}$} & -0.192 & & -0.185 & & -0.127 & & -0.130 & \\
\hline & -2.142 & $* *$ & -2.071 & $* *$ & -1.803 & $*$ & -1.850 & * \\
\hline \multirow[t]{2}{*}{$A C \_F I N \_E X P E R T^{*} D R^{*} R_{i t}$} & 0.235 & & 0.231 & & 0.208 & & 0.210 & \\
\hline & 2.008 & $* *$ & 1.981 & $* *$ & 2.175 & $* *$ & 2.204 & $* *$ \\
\hline \multirow[t]{2}{*}{ AC_ASSOC $i t$} & -0.886 & & -1.001 & & -0.403 & & -0.381 & \\
\hline & -0.303 & & -0.343 & & -0.158 & & -0.149 & \\
\hline \multirow[t]{2}{*}{$A C \_A S S O C * D R_{i t}$} & 3.450 & & 3.738 & & -1.065 & & -1.121 & \\
\hline & 0.890 & & 0.967 & & -0.300 & & -0.316 & \\
\hline \multirow[t]{2}{*}{$A C \_A S S O C * R_{i t}$} & 3.400 & & 3.990 & & 6.048 & & 6.090 & \\
\hline & 0.600 & & 0.707 & & 1.218 & & 1.227 & \\
\hline \multirow[t]{2}{*}{$A C \_A S S O C * D R^{*} R_{i t}$} & 3.059 & & 2.739 & & -11.346 & & -11.347 & \\
\hline & 0.453 & & 0.407 & & -1.722 & $*$ & -1.724 & $*$ \\
\hline \multirow[t]{2}{*}{$A C \_N E D_{i t}$} & 0.062 & & 0.052 & & -0.093 & & -0.093 & \\
\hline & 1.242 & & 1.049 & & -1.791 & $*$ & -1.752 & $*$ \\
\hline \multirow[t]{2}{*}{$A C_{-} N E D^{*} D R_{i t}$} & -0.024 & & -0.010 & & 0.014 & & 0.002 & \\
\hline & -0.350 & & -0.147 & & 0.180 & & 0.021 & \\
\hline \multirow[t]{2}{*}{$A C \_N E D^{*} R_{i t}$} & -0.260 & & -0.249 & & 0.122 & & 0.128 & \\
\hline & -2.953 & $* * *$ & -2.843 & $* * *$ & 1.373 & & 1.440 & \\
\hline \multirow[t]{2}{*}{$A C \_N E D^{*} D R^{*} R_{i t}$} & 0.266 & & 0.261 & & -0.238 & & -0.251 & \\
\hline & 2.367 & $* * *$ & 2.328 & $* *$ & -1.894 & $*$ & -1.992 & ** \\
\hline \multirow[t]{2}{*}{$A C \_I N D_{i t}$} & 0.052 & & 0.051 & & 0.065 & & 0.067 & \\
\hline & 0.709 & & 0.693 & & 1.457 & & 1.515 & \\
\hline \multirow[t]{2}{*}{$A C \_I N D * D R_{i t}$} & -0.054 & & -0.057 & & 0.020 & & 0.019 & \\
\hline & -0.548 & & -0.580 & & 0.327 & & 0.311 & \\
\hline \multirow[t]{2}{*}{$A C \_I N D * R_{i t}$} & -0.159 & & -0.157 & & -0.058 & & -0.058 & \\
\hline & -1.352 & & -1.341 & & -0.791 & & -0.791 & \\
\hline \multirow[t]{2}{*}{$A C \_I N D^{*} D R^{*} R_{i t}$} & 0.184 & & 0.180 & & 0.176 & & 0.180 & \\
\hline & 1.093 & & 1.068 & & 1.738 & * & 1.773 & $*$ \\
\hline \multirow[t]{2}{*}{$A C M E E T_{i t}$} & 0.090 & & 0.081 & & -1.744 & & -1.734 & \\
\hline & 0.178 & & 0.161 & & -3.475 & $* * *$ & -3.456 & $* * *$ \\
\hline \multirow[t]{2}{*}{$A C M E E T^{*} D R_{i t}$} & -0.109 & & -0.053 & & 1.724 & & 1.729 & \\
\hline & -0.162 & & -0.079 & & 2.589 & $* * *$ & 2.599 & $* * *$ \\
\hline \multirow[t]{2}{*}{$A C M E E T^{*} R_{i t}$} & 0.061 & & 0.102 & & 3.327 & & 3.310 & \\
\hline & 0.066 & & 0.111 & & 4.032 & $* * *$ & 4.011 & $* * *$ \\
\hline \multirow[t]{2}{*}{$A C M E E T^{*} D R^{*} R_{i t}$} & -0.921 & & -0.970 & & -3.128 & & -3.139 & \\
\hline & -0.830 & & -0.877 & & -2.977 & $* * *$ & -2.989 & $* * *$ \\
\hline
\end{tabular}


Table 5(continued)

\begin{tabular}{lcccc}
\hline \hline ACMEET_AUD it & 0.515 & 0.636 & 0.537 & 0.616 \\
& 0.394 & 0.489 & 0.673 & 0.755 \\
ACMEET_AUD*DR $R_{\text {it }}$ & -1.209 & -1.559 & -0.595 & -0.722 \\
& -0.654 & -0.845 & -0.520 & -0.628 \\
ACMEET_AUD* $R_{i t}$ & 0.569 & 0.318 & -1.061 & -1.130 \\
& 0.305 & 0.171 & -0.768 & -0.817 \\
ACMEET_AUD*DR* $R_{i t}$ & -0.519 & -0.431 & 2.167 & 2.288 \\
& -0.191 & -0.159 & 1.125 & 1.188 \\
Period fixed & & & & No \\
Industry Fixed & Yes & No & Yes & Yes \\
Adjusted R & Yes & Yes & Yes & \\
F-statistic & & & & 0.045 \\
\hline
\end{tabular}

Please refer Table 1 for variables description. *,** and ***denote significance at the 10 percent, 5 percent and 1 percent level respectively. 
Table 6: Accrual-based loss recognition

\begin{tabular}{|c|c|c|c|c|c|c|c|c|}
\hline \multirow[b]{2}{*}{ Variable } & \multicolumn{3}{|c|}{$\begin{array}{l}\text { Pre-MCCG :ACC } \\
\text { (n-1384) }\end{array}$} & \multicolumn{5}{|c|}{$\begin{array}{c}\text { Post-MCCG : ACC } \\
\text { (n-1799) }\end{array}$} \\
\hline & $\begin{array}{c}\text { Coefficient } \\
1\end{array}$ & & $\begin{array}{c}\text { Coefficient } \\
2\end{array}$ & & $\begin{array}{c}\text { Coefficient } \\
3\end{array}$ & & $\begin{array}{c}\text { Coefficient } \\
4\end{array}$ & \\
\hline \multirow[t]{2}{*}{$C_{i t}$} & -0.103 & & -0.102 & & -0.046 & & -0.019 & \\
\hline & -1.605 & & -1.583 & & -0.968 & & -0.403 & \\
\hline \multirow[t]{2}{*}{$D_{C F O}{ }_{i t}$} & 0.184 & & 0.185 & & 0.144 & & 0.142 & \\
\hline & 1.741 & * & 1.750 & * & 2.044 & $* *$ & 2.019 & $* *$ \\
\hline \multirow[t]{2}{*}{$C F O_{i t}$} & 0.739 & & 0.721 & & 0.470 & & 0.486 & \\
\hline & 1.303 & & 1.273 & & 1.273 & & 1.312 & \\
\hline \multirow[t]{2}{*}{$D C F O * C F O_{i t}$} & -0.264 & & -0.240 & & -0.862 & & -0.886 & \\
\hline & -0.219 & & -0.199 & & -1.284 & & -1.315 & \\
\hline \multirow[t]{2}{*}{$A C C \_E X P E R T_{i t}$} & -0.001 & & -0.001 & & -0.001 & & -0.001 & \\
\hline & -1.016 & & -0.999 & & -2.929 & $* * *$ & -2.846 & $* * *$ \\
\hline \multirow[t]{2}{*}{ ACC_EXPERT*DCFO ${ }$ it } & 0.001 & & 0.001 & & 0.001 & & 0.001 & \\
\hline & 0.877 & & 0.874 & & 1.961 & * & 1.857 & * \\
\hline \multirow[t]{2}{*}{$A C C \_E X P E R T^{*} C F O_{i t}$} & 0.012 & & 0.012 & & 0.012 & & 0.012 & \\
\hline & 1.707 & * & 1.693 & * & 3.896 & $* * *$ & 3.784 & $* * *$ \\
\hline \multirow[t]{2}{*}{ ACC_EXPERT ${ }^{*} D C F O * C F O_{i t}$} & 0.029 & & 0.030 & & 0.004 & & 0.004 & \\
\hline & 2.163 & $* *$ & 2.236 & $* *$ & 0.385 & & 0.450 & \\
\hline \multirow[t]{2}{*}{$F I N \_E X P E R T_{i t}$} & 0.003 & & 0.003 & & 0.000 & & 0.000 & \\
\hline & 2.524 & $* *$ & 2.534 & $* *$ & -0.144 & & -0.174 & \\
\hline \multirow[t]{2}{*}{$F I N \_E X P E R T^{*} D C F O_{i t}$} & -0.004 & & -0.004 & & -0.002 & & -0.002 & \\
\hline & -1.780 & $*$ & -1.791 & * & -1.114 & & -1.238 & \\
\hline \multirow[t]{2}{*}{$F I N \_E X P E R T^{*} C F O_{i t}$} & -0.027 & & -0.027 & & 0.000 & & 0.001 & \\
\hline & -2.692 & $* *$ & -2.707 & $* *$ & 0.055 & & 0.127 & \\
\hline \multirow[t]{2}{*}{$F I N \_E X P E R T^{*} D C F O * C F O_{i t}$} & -0.043 & & -0.045 & & 0.019 & & 0.016 & \\
\hline & -1.321 & & -1.362 & & 0.933 & & 0.774 & \\
\hline
\end{tabular}

(The table is continued on the next page) 


\begin{tabular}{|c|c|c|c|c|c|c|c|c|}
\hline \multirow[t]{2}{*}{$A C \_F I N \_E X P E R T_{i t}$} & 0.001 & & 0.001 & & 0.001 & & 0.001 & \\
\hline & 1.112 & & 1.104 & & 2.289 & $* *$ & 2.309 & $* *$ \\
\hline \multirow[t]{2}{*}{$A C \_F I N \_E X P E R T^{*} D C F O_{i t}$} & 0.000 & & 0.000 & & 0.000 & & 0.000 & \\
\hline & -0.099 & & -0.095 & & 0.168 & & 0.135 & \\
\hline \multirow[t]{2}{*}{$A C \_F I N \_E X P E R T^{*} C F O_{i t}$} & -0.011 & & -0.011 & & -0.009 & & -0.009 & \\
\hline & -2.245 & ** & -2.275 & ** & -3.421 & $* * *$ & -3.451 & *** \\
\hline \multirow[t]{2}{*}{$A C \_F I N \_E X P E R T * D C F O * C F O_{i t}$} & -0.009 & & -0.009 & & 0.031 & & 0.031 & \\
\hline & -0.778 & & -0.778 & & 5.194 & $* * *$ & 5.047 & $* * *$ \\
\hline \multirow[t]{2}{*}{$A C \_A S S O C_{i t}$} & 0.074 & & 0.076 & & 0.001 & & 0.000 & \\
\hline & 2.793 & $* * *$ & 2.842 & $* * *$ & 0.046 & & 0.017 & \\
\hline \multirow[t]{2}{*}{$A C \_A S S O C^{*} D C F O_{i t}$} & -0.166 & & -0.170 & & -0.117 & & -0.119 & \\
\hline & -3.253 & $* * *$ & -3.330 & $* * *$ & -3.513 & $* * *$ & -3.562 & $* * *$ \\
\hline \multirow[t]{2}{*}{$A C \_A S S O C^{*} C F O_{i t}$} & -0.560 & & -0.577 & & -0.189 & & -0.176 & \\
\hline & -2.132 & $* *$ & -2.201 & $* *$ & -1.167 & & -1.080 & \\
\hline \multirow[t]{2}{*}{$A C \_A S S O C^{*} D C F O * C F O_{i t}$} & -2.493 & & -2.494 & & -2.770 & & -2.805 & \\
\hline & -4.022 & $* * *$ & -4.026 & $* * *$ & -7.420 & $* * *$ & -7.493 & $* * *$ \\
\hline \multirow[t]{2}{*}{$A C \_N E D_{i t}$} & -0.001 & & -0.001 & & 0.000 & & 0.000 & \\
\hline & -1.170 & & -1.179 & & -0.263 & & -0.874 & \\
\hline \multirow[t]{2}{*}{$A C \_N E D * D C F O_{i t}$} & 0.003 & & 0.003 & & 0.000 & & 0.000 & \\
\hline & 3.171 & $* * *$ & 3.131 & $* * *$ & -0.305 & & -0.227 & \\
\hline \multirow[t]{2}{*}{$A C \_N E D^{*} C F O_{i t}$} & 0.002 & & 0.002 & & 0.003 & & 0.003 & \\
\hline & 0.415 & & 0.484 & & 0.746 & & 0.739 & \\
\hline \multirow[t]{2}{*}{$A C \_N E D^{*} D C F O^{*} C F O_{i t}$} & 0.094 & & 0.093 & & -0.007 & & -0.007 & \\
\hline & 6.146 & $* * *$ & 6.104 & $* * *$ & -0.859 & & -0.877 & \\
\hline \multirow[t]{2}{*}{$A C \_I N D_{i t}$} & 0.001 & & 0.001 & & 0.001 & & 0.001 & \\
\hline & 0.879 & & 0.860 & & 2.551 & $* *$ & 2.500 & $* *$ \\
\hline \multirow[t]{2}{*}{$A C \_I N D * D C F O_{i t}$} & -0.002 & & -0.002 & & -0.002 & & -0.002 & \\
\hline & -1.726 & $*$ & -1.666 & $*$ & -3.689 & $* * *$ & -3.688 & $* * *$ \\
\hline \multirow[t]{2}{*}{$A C \_I N D^{*} C F O_{i t}$} & 0.001 & & 0.002 & & -0.010 & & -0.011 & \\
\hline & 0.213 & & 0.227 & & -3.990 & $* * *$ & -4.200 & $* * *$ \\
\hline \multirow[t]{2}{*}{$A C \_I N D * D C F O * C F O_{i t}$} & -0.068 & & -0.067 & & -0.006 & & -0.005 & \\
\hline & -3.512 & $* * *$ & -3.498 & $* * *$ & -0.852 & & -0.668 & \\
\hline
\end{tabular}

(The table is continued on the next page) 


\begin{tabular}{|c|c|c|c|c|c|c|c|c|}
\hline \multirow[t]{2}{*}{$A_{C M E E T_{i t}}$} & 0.003 & & 0.003 & & -0.002 & & -0.002 & \\
\hline & 0.509 & & 0.493 & & -0.523 & & -0.571 & \\
\hline \multirow[t]{2}{*}{$A C M E E T^{*} D C F O_{i t}$} & -0.014 & & -0.014 & & 0.025 & & 0.025 & \\
\hline & -1.617 & & -1.633 & & 3.756 & $* * *$ & 3.785 & $* * *$ \\
\hline \multirow[t]{2}{*}{$A C M E E T^{*} C F O_{i t}$} & -0.106 & & -0.104 & & -0.045 & & -0.041 & \\
\hline & -2.106 & $* *$ & -2.075 & ** & -1.326 & & -1.208 & \\
\hline \multirow[t]{2}{*}{$A C M E E T^{*} D C F O * C F O_{i t}$} & -0.070 & & -0.074 & & 0.562 & & 0.558 & \\
\hline & -0.531 & & -0.562 & & 11.146 & $* * *$ & 11.039 & $* * *$ \\
\hline \multirow{2}{*}{ ACMEET_AUD $D_{i t}$} & 0.018 & & 0.018 & & 0.001 & & -0.002 & \\
\hline & 1.431 & & 1.448 & & 0.232 & & -0.285 & \\
\hline \multirow[t]{2}{*}{ ACMEET_AUD*DCFO ${ }_{i t}$} & 0.009 & & 0.012 & & 0.017 & & 0.018 & \\
\hline & 0.329 & & 0.419 & & 1.508 & & 1.633 & \\
\hline \multirow[t]{2}{*}{ ACMEET_AUD*CFO ${ }_{i t}$} & -0.032 & & -0.036 & & 0.111 & & 0.118 & \\
\hline & -0.301 & & -0.335 & & 2.103 & ** & 2.235 & $* *$ \\
\hline \multirow[t]{2}{*}{ ACMEET_AUD*DCFO*CFO ${ }^{*}$} & 0.389 & & 0.415 & & -0.018 & & -0.014 & \\
\hline & 0.764 & & 0.816 & & -0.175 & & -0.137 & \\
\hline Industry fixed & Yes & & Yes & & Yes & & Yes & \\
\hline Period fixed & Yes & & No & & Yes & & No & \\
\hline Adjusted $R^{2}$ & 0.945 & & 0.945 & & 0.955 & & 0.956 & \\
\hline
\end{tabular}

Please refer Table 1 for variables description. . *, ** and ***denote significance at the 10 percent, 5 percent and 1 percent level respectively. 